be trusted in the latter capacity, he ought never to have bcen chosen to fill an Oxford chair. In short, as the representative of physiology in Oxford, Dr. Sanderson, by the nature and extent of his concession, has drawn a clear distinction between the importance of teaching and of research: he has consentcd to allow the teaching to suffer if needs be ; but he will not consent to yield an inch where the principles of research are concerned.

The other suggestion which was thrown out by Canon Liddon-namely, that a Professor of Physiology ought to pledge himself to kill every animal before it recovers from its anæesthesia-is, from every point of view, absurd. In the first place, the suggestion can only emanate from the uninformed supposition that the pain of a healing wound is considerable. But we know from the experience of hospital practice that even the most severe wounds are painless while healing, unless the process of healing is complicated by morbid conditions, which now admit of being wholly prevented by antiseptic methods. As a matter of fact, therefore, in our physiological laboratories, as in our surgical wards, there is at the present time but an extremely small amount of suffering to be found in connection with the healing of wounds; and no man of ordinary sense who had ever seen the inside of either the one or the other would have cared to make the suggestion which we are considering. But, in the next place, even if this were not so, it would thave been highly wrong in any Professor of Physiology to restrict himself to the performance of cxperiments the objects of which could be secured during the action of an anasthetic. Certainly more than half the experiments which the physiologist has now to perform have reference to questions of aftereffects, and this is especially the case in experiments bearing upon the problems of pathology.

The speech of the I3ishop of Oxford was bad, both in logic and in taste. It was bad in logic because in arguing for the total suppression of physiological research in Oxford, he relied upon foreign practice for his evidence of cruelty. This was essentially illogical, because it fails to distinguish between two very different things-namely, the cruelty, if any, which attaches to vivisection per se, and the cruelty which arises from other sources. If the state of public feeling in some foreign countries is not so sensitive as it is in our own on the matter of inflicting pain upon the lower animals, it is obviously unfair to search through the Continent for instances of cruelty in connection with physiological research, and then to adduce such instances as proof of cruelty necessarily attaching to physiological research at home. We might as well argue against the use of mules in England because these animals are badly treated in Spain. As we have already said, there are now but extremely few cases possible in which the occurrence of pain is necessary for the purposes of an expcriment; and therefore the proof of pain having been inflicted in any one case constitutes proof, not of the pain-giving character of vivisection in general, but of the carelessness of some operator in particular. The cruelty must belong to the individual, not to the methods; and we are not aware that any charge of cruelty has hitherto been proved against an English physiologist.

The Bishop of Oxford's speech was bad in taste, because he sought, missionary-wise, to tell some anecdote of horror, which the good sense of Convocation prevented him from narrating further than that the subject of his story was to have been "an affectionate little dog." But, as he was not able to give any reference to the scene of his tragedy, after a prolonged battle with his audience upon this somewhat necessary proof of authenticity, he was obliged to give way. His taste was perhaps still more questionable when, in the presence of Prof. Sanderson and other working physiologists, he proceeded to adduce the favourite argument that the pursuit of experimental physiology exercises a baleful influence on the moral nature. That the argument is unsound, both in principle and in fact, we need not wait to show.

The speech of Prof. Freeman was rendered wholly inaudible by a general uproar, which proceeded chiefly from the side which he rose to support. We were told that this was due to the memory of the effect which was produced by his speech on the occasion of the previous vote.

Upon the whole we think that the debate was of no little service to the cause of physiology in Oxford; and when we consider how largely the majority of votes has grown since the first of the three divisions, we are glad to congratulate the University upon having shown so emphatically that, not less than her sister, she is able to withstand the assaults of the two great enemies of learning--Ignorance and Fanaticism.

\section{THE RELATIVE EFFICIENCY OF WARSHIPS}

I $N$ our last week's issue we published a letter from Sir

Edward Reed adverting to some points in an article which appeared in our number of February 26 upon "The Relative Efficiency of War Ships." In order to show the difference existing between the ships of the Inflexible or Agamemnon class and those of the Admiral class, as regards height of armour above the water, we then gave profiles of the Agamemnon and of the Collingwood (one of the Admiral class). We now give outline sections of the same vessels, in which this large difference can be more clearly seen, and by means of which its importance can be better understood.

Before giving any figures in connection with this question it may be as well to mention another point which, taken alone, is not unworthy of notice. We refer to the difference betwcen the Agamemnon and Collingwood with regard to depth of armour below the water. When the Agamemnon is floating in smooth water, with her unarmoured ends uninjured, the depth of her armour below the water-line is 5 feet ro inches, whereas that of the Collingwood, under the same conditions, is only 5 feet, as shown in Figs. I and 2 respectively. This difference of nearly $\mathrm{I}$ foot is of some importance, because every two or three inches gained in depth of armour below the water means a large increase in the safety of the ship when fighting at sea. When the ends of the Agamemnon are flooded she sinks 22 inches deeper in the water, and the depth of her armour below its surface would, therefore, then be 7 feet 8 inches (Fig. 3). The Collingwood, when her ends are flooded, sinks $17 \frac{1}{2}$ inches deeper in the water, and in that condition, therefore, her armour would be 6 feet $5_{2}^{\frac{1}{2}}$ inches below the water's surface (Fig. 4), or I foot $2 \frac{1}{2}$ inches less than that of the Agamemnon. In the earlier ironclads it was considered necessary to carry 
the armour to a depth of at least 6 feet below the normal water-line, and as much deeper as individual cases would allow. It is evident, therefore, that the ships of the Admiral class are deficient in this respect unless and until their unarmoured ends are flooded.
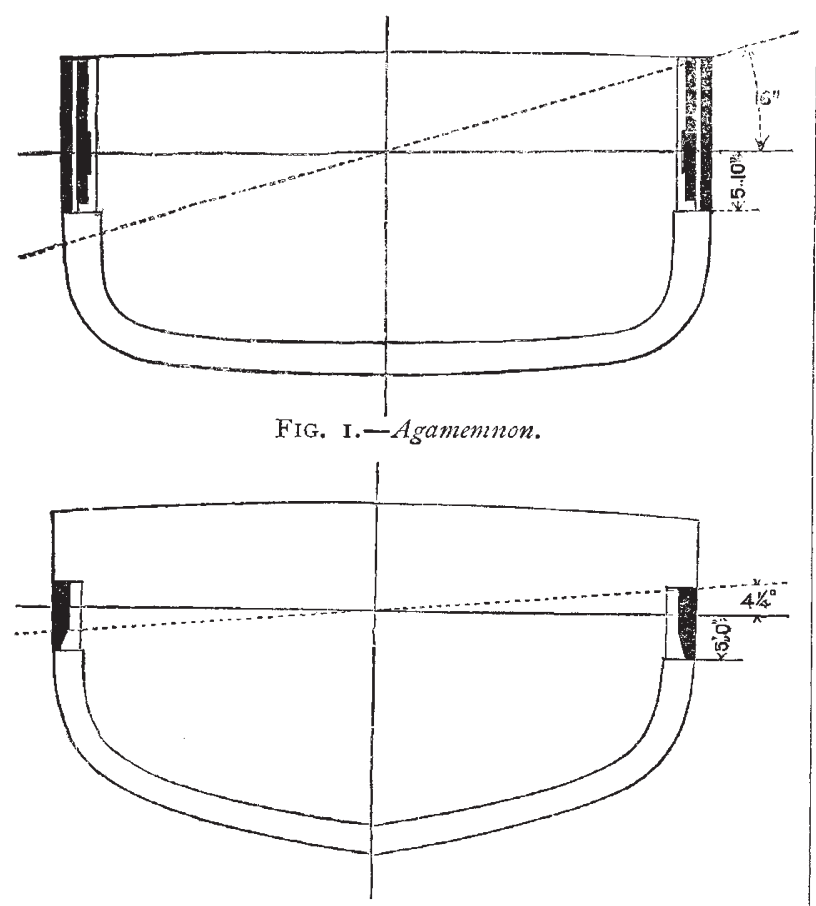

FIG. 2.-Collingrerood.

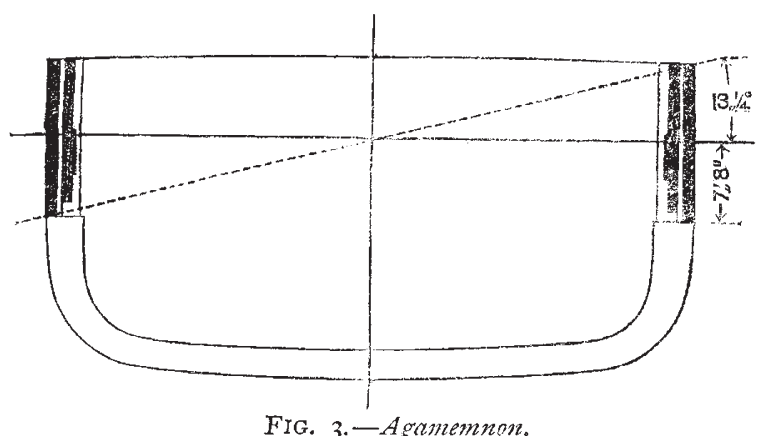

FIG. 3.-Agamemnon.

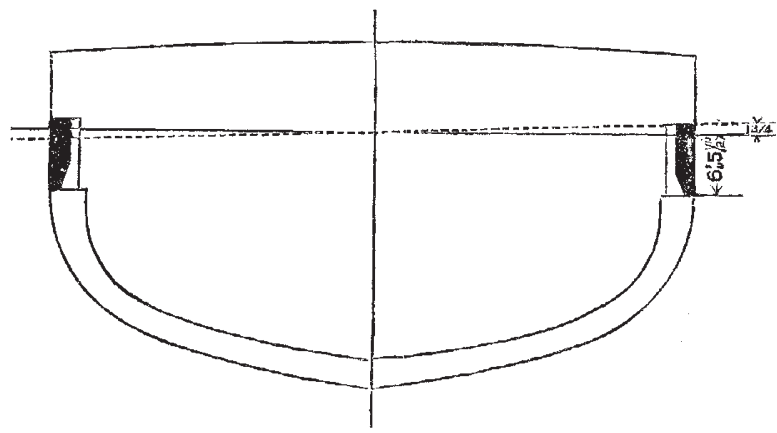

FIG. 4.-Collingwood.

Reverting to the still more important question of height of armoured freeboard (i.e. the height of the top edge of armour at side above the water), we will now give some figures. The Agamemnon, with her armoured freeboard of 9 feet 6 inches in the uninjured condition, can be inclined to the angle of 16 degrees before the top edge of her armour touches the water, as shown by the dotted line in Fig. I ; and even when her unarmoured ends are flooded, and her freeboard therefore rcduced to 7 feet 8 inches, she can still be inclined (assuming for the moment that she would still have stability) to the angle of $13^{\frac{1}{4}}$ degrees before her armour is brought beneath the water; this is shown in Fig. 3. But the Collingwood has so ridiculously shaliow a partial belt (only 2 feet 6 inches above the water in the uninjured condition) that an inclination of only $4 \frac{1}{4}$ degrees causes her armour to clisappcar altogether in smooth water. When her ends are flooded her armoured freeboard is actually reduced to no more than $\mathrm{I} 2 \frac{1}{2}$ inches, which is as much as to say that at sea she would have no armoured freeboard at all in that condition, for an inclination of tut I $\frac{3}{4}$ degrees is sufficient to bury her armour completely, even in smooth water. The two conditions of the Collingwood are shown in Fig. 2 and Fig. 4 respectively.

These alarming facts, thus clearly brought into view are of themselves sufficient to explain Sir Edward Reed's distrust of the Admiral class of ship, and his very strong condemnation of these ships can be readily understood when we remember, further, that in his opinion the excessive shortening of the armoured part in the whole of these ships has introduced such elements of danger into them as to render them unfit to take their place in the line of battle, even apart from the considerations previously set forth.

\section{THE AMERICAN ASSOCIATION}

Proceedings of the American Association for the Advancement of Science (Thirty-Second Meeting), held at Minneapolis, Minn., August, i883. (Salem: Published by the Permanent Secretary, I884.)

THE record of the proceedings of the thirty-second 1 meeting of the American Association forms a volume considerably less bulky than that issued by the British Association, as it consists of 598 pages, the corresponding volume of the older Association numbering 884 pages. The difference between the two volumes, as records of science, is about in the same proportion. Addresses, reports, and abstracts of papers take up 468 pages in the book before us, while in the Southport volume the same subjects occupy 660 pages. In printing and paper the American volume is decidedly the superior of the British, but, as a set-off, it is issued in a paper cover; the price, however, is only $I^{\circ} 50$ dollars. The smaller size of the volume is accounted for by the fact that considerably fewer papers appear to have been read before the American Association than before the British. We note also another point of difference, certainly not to the advantage of the American volume: the reports on the state of science, so conspicuous and valuable a fcature in the British volume, are remarkable in the American chiefly by their absence. We venture to suggest to the officers and Committee of the latter Association that they would add largely to its importance and stability by developing this branch of its work. At the present time, when scientific societies for special purposes are so numerous, their meetings and journals will always compete successfully with those of an all-embracing Association such as the British and others formed on a similar plan 